ISSN: 0213-2079 - ISSN electrónico: 2386-3889

DOI: http://dx.doi.org/10.14201/shhmo201537123151

\title{
ELITE HIDALGA Y PODER SEÑORIAL EN GALICIA: PRINCIPALES MECANISMOS DE ACCESO (1480-1650)
}

\section{The Elite of Hidalgos and the Lordly Power in Galicia: main Strategies for Acquiring a Manor (1480-1650)}

Antonio PRESEDO GARAZO

Universidad de Vigo

Correo-e: antonio.presedo@uvigo.es

RESUMEN: Al igual que en el resto de la Corona de Castilla, el señorío representó en Galicia durante la Edad Moderna una célula básica de convivencia diaria para las comunidades locales, y un territorio delimitado que se hallaba sometido a la jurisdicción de un señor que, debido a dicha condición señorial, era depositario de una serie de ingresos y potestades que contribuían a reforzar su poder en el ámbito local. Partiendo del hecho demostrado de que entre los pequeños y muy pequeños señores de vasallos abundaban los hidalgos, nos hemos propuesto, en el presente artículo, analizar los mecanismos de que se valieron estos para acceder al señorío y la conflictividad que generó dicho proceso a lo largo del siglo XVI y primera mitad del xvir.

Palabras clave: señorío; poder local; nobleza; hidalgos; siglos XVI y XVII.

ABSTRACT: Manor was in Early Modern Galicia, just like in the rest of the kingdom of Castile, a basic cell of everyday good-fellowship in local communities, and a delimited territory under a lord's jurisdiction, who was

1. Trabajo iniciado en el marco del Proyecto de Investigación HAR2008-02026/HIST, subvencionado por el Ministerio de Ciencia e Innovación (MINCIN), y finalizado dentro del Proyecto de Investigación HAR2012-37007, subvencionado por el Ministerio de Economía y Competitividad (MINECO), ambos dirigidos por M. ${ }^{a}$ López Díaz. 
the receiver of incomes and powers that helped to strengthen its power on a local scale. Taking the demonstrated fact about the great abundance of hidalgos in the little lords and very little ones as a starting point, we analyze in this work the strategies that they used for acquiring one manor, and the tensions and disputes that were generated by this process besides, during the Sixteenth and the first mid-Seventeenth centuries.

Key words: Manor; Local Power; Nobility; Hidalgos; Sixteenth \& Seventeenth Centuries.

\section{INTRODUCCIÓN}

El reino de Galicia fue a lo largo de toda la Edad Moderna un territorio en el que los señores jurisdiccionales ejercieron un gran poder $^{2}$. La mayor parte de este territorio del noroeste peninsular, fragmentado en una densa -en ocasiones tupidared jurisdiccional ${ }^{3}$, y de su población, se hallaban bajo la órbita de influencia de la jurisdicción señorial; dando lugar a «un mosaico bien irregular» cuyas líneas fundamentales habían sido trazadas mucho antes, incluso, en bastantes señoríos, previamente a $1500^{4}$.

En el marco político-institucional vigente en dicha época histórica en la Corona de Castilla, el señorío venía desempeñando en la práctica, desde la Edad Media ${ }^{5}$, una función vertebradora del territorio y del gobierno local, toda vez que la Monarquía había delegado algunas de sus competencias judiciales y gubernamentales en los señores jurisdiccionales; no solo con el objeto de recompensarles por los

2. Eiras Roel, A.: «El señorío gallego en cifras. Nómina y ranking de los señores jurisdiccionales», Cuadernos de Estudios Gallegos, XXXVIII, 1989, pp. 113-135 y «El régimen señorial en Galicia a finales de la Edad Moderna: Evaluación», Obradoiro de Historia Moderna, 6, 1997, pp. 7-46. El primero de ambos trabajos ha influido notablemente en las posteriores investigaciones realizadas por los modernistas gallegos en relación con esta temática, tal como han puesto de manifiesto en sus exhaustivas revisiones historiográficas López Díaz, M. ${ }^{a}$ y SaAvedra Vázquez, M. ${ }^{a}$ C.: «Historia política y de las instituciones del Antiguo Régimen en Galicia», en López López, R. J. y GonzÁLez Lopo, D. L. (eds.): Balance de la Historiografía Modernista, 1973-2001. Santiago de Compostela, 2003, pp. 126-134; y Pérez García, J. M. y López Díaz, M.a: «La historiografía modernista de Galicia: balance historiográfico (1988-2008)», Minius. Historia, Arte e Xeografía, 18, 2010, pp. 178-181.

3. Río BarJa, F. X.: Cartografía xurisdiccional de Galicia no século XVIII. Santiago de Compostela, 1990; Gallego Domínguez, O.: La organización administrativa territorial de la antigua provincia de Ourense a mediados del siglo XVIII. Orense, 1988; Erias Martínez, A. y González Fernández, X. M.: «O marco xurisdiccional na antiga provincia de Betanzos», Anuario Brigantino, 12, 1989, pp. 17-84.

4. SaAvedra Fernández, P.: «Régimen señorial y administración local en la Galicia de los siglos xvi-Xviiı», en Barreiro Fernández, X. R. y González Mariñas, P. (coords.): Historia da Administración. Santiago de Compostela, 1994, p. 35.

5. Moxó, S. de: «El señorío, legado medieval», Cuadernos de Historia, 1, 1967, pp. 105 y ss. 
servicios que estos les hubiesen podido prestar previamente, sino también para que contribuyesen a garantizar la gobernabilidad de los dominios recibidos 6 . Por ello, los señores jurisdiccionales acostumbraban a disfrutar de amplios poderes -derivados de las regalías de que son depositarios sus titulares-dentro de los límites comprendidos por sus señoríos, con diferencias importantes que se constatan si atendemos a variables como la extensión que estos pueden llegar a comprender, el número de sus vasallos, o el volumen y la tipología de los ingresos que generan.

Al igual que en otras zonas de la Península ibérica ${ }^{7}$, el señorío secular también predomina en la Galicia tardofeudal, si bien el primer puesto en extensión y número de vasallos le corresponde al arzobispo de Santiago $^{8}$, y tanto el monasterio benedictino de Celanova como el obispo de Mondoñedo figuran entre los diez primeros si atendemos a ambos parámetros ${ }^{9}$. Siguiendo a A. Eiras Roel, en la segunda mitad del siglo xviII, algo más del 54\% de su territorio y del $48 \%$ de su población están sometidos a la jurisdicción de 46 casas nobles tituladas y otras 97 casas hidalgas que se reparten el señorío secular gallego, el cual presenta un carácter marcadamente rural, habida cuenta de su hegemonía en la Galicia interior -donde destaca de manera especial la provincia de Lugo- y de que ninguno de los núcleos urbanos de importancia se halla bajo el dominio nobiliario ${ }^{10}$. De estos 143 señores jurisdiccionales nobles, sobre un global de 206, han merecido mayor atención hasta el presente los condados de Altamira, Lemos, Monterrei y Ribadavia, que forman parte de una minoría selecta compuesta por los diez grandes señores galaicos capaces

6. Esta transferencia de poder desde la Monarquía hacia los señores castellanos, y concretamente los señores nobles, ha sido analizada, entre otros, por Atienza Hernández, I.: Aristocracia, poder y riqueza en la España moderna. La Casa de Osuna, siglos XV-XIX. Madrid, 1987, pp. 35-36; BENíTeZ SÁnchez-Blanco, R.: "Nobleza y señorío: el método», Cuadernos de Historia Moderna, 15, 1994, pp. 381-382; Bermejo Cabrero, J. L.: «Sobre nobleza, señoríos y mayorazgos», Anuario de Historia del Derecho Español, LV, 1985, pp. 263-268; Carrasco Martínez, A.: El régimen señorial en la Castilla moderna: las tierras de la Casa del Infantado en los siglos XVII y XVIII. Madrid, 1991, pp. 167

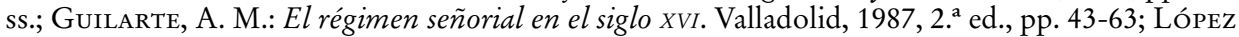
DíAz, M.a: "La administración de la justicia señorial en el antiguo régimen», Anuario de Historia del Derecho Español, LXXVI, 2006, pp. 559-560; y García Hernán, D.: El gobierno señorial en Castilla. La presión y concesión nobiliaria en sus documentos (siglos XVI-XVIII). Madrid, 2010.

7. Cfr. Ardit, M.: «La historia rural de la España oriental durante la Edad Moderna: un estado de la cuestión», Stvdia Historica. Historia Moderna, 29, 2007, pp. 69-70; BLESA Cuñat, E.: «El règim senyorial valencià vespres de la seua dissolució», Estudis d'Historia Contemporània del País Valencià, 1, 1979, p. 182; y Yun Casalilla, B.: «Notas sobre el régimen señorial en Valladolid y el estado señorial de Medina de Rioseco en el siglo XVII", Investigaciones Históricas, 3, 1982, pp. 149 y 153.

8. Para la Alta Edad Moderna, vid. López DíAz, M.': Señorío y Municipalidad. Concurrencia $y$ conflicto de poderes en la ciudad de Santiago (siglos XVI-XVII). Santiago de Compostela, 1997, 2. ${ }^{a}$ parte.

9. Eiras Roel, A.: «El señorío gallego...», pp. 125-126 y tabla 2, p. 131.

10. Idem, pp. 119-128. 
de superar los 5.000 vasallos en $1760^{11}$; lo cual se debe, principalmente, al gran poder que acumularon estas casas condales en el transcurso de la Baja Edad Media y que lograron mantener durante los siglos modernos ${ }^{12}$.

No obstante, son los 95 hidalgos sin título, abundantes entre los pequeños o muy pequeños señores de vasallos, los que realmente destacan en la nómina de señores jurisdiccionales de la Galicia dieciochesca si atendemos a su peso numérico, ya que suponen un $46,11 \%$ de todos ellos; si bien, dicho porcentaje contrasta con la reducida o muy reducida extensión territorial y el exiguo número de vasallos que, por término medio, les corresponde a cada uno: 119 en $1760^{13}$. Precisamente, ha sido esta participación más limitada en el ejercicio del poder señorial -en comparación con los grandes señoríos y aquellos otros de nivel medio-, unida a la dificultad que plantea la localización de fuentes históricas adecuadas para acometer su estudio, la que explica, en buena medida, el hecho de que todavía no se hayan analizado en profundidad las consecuencias económicas y políticas que se derivaron del acceso al señorío jurisdiccional por parte de este sector minoritario de la pequeña y mediana nobleza gallega, y que se manifestaron en el ámbito local. Los estudios monográficos sobre Casas hidalgas que se realizaron a lo largo de la última década en base a la consulta sistemática de archivos familiares privados, y que fructificaron en la elaboración de memorias de licenciatura y tesis doctorales, han puesto de manifiesto que se trata de una temática fundamental para conocer cuáles fueron las estrategias que desplegaron sus dueños para preservar su poder y su preeminencia social a lo largo de los siglos modernos ${ }^{14}$. Aunque conviene no perder de vista que

11. Se han ocupado del ámbito señorial de estas cuatro casas condales, Baz Vicente, M. J.: Señorío y propiedad foral de la alta nobleza en Galicia (siglos XVI-XX): La Casa de Alba. Madrid, 1996; FERNÁNDEZ SuÁrez, G. F.: «La administración del Condado de Ribadavia en el siglo xv: organización político-judicial, hacienda, milicia, casa y comitiva», Semata. Ciencias Sociais e Humanidades, 15, 2004, pp. 343-361; García AcuÑA, M. ${ }^{a}$ L.: «Mecanismos de control señorial: Los juicios de residencia en el Estado de Ribadavia», Obradoiro de Historia Moderna, 5, 1996, pp. 119-134; SAAvedra Fernández, P.: "Contribución al estudio del régimen señorial gallego», Anuario de Historia del Derecho Español, LIX, 1990, pp. 103-184, «Régimen señorial y administración local...» y «La administración señorial en la Galicia Moderna», Hispania. Revista Española de Historia, 198, 1998, pp. 185-212.

12. Baz Vicente, op. cit.; Fernández SuÁreZ, G. F.: La Nobleza Gallega entre los siglos XIV-XV. Los Sarmiento condes de Ribadavia. Santiago de Compostela, 2002; García Oro, J.: La nobleza gallega en la Baja Edad Media. Las casas nobles y sus relaciones estamentales. Santiago de Compostela, 1981; García Oro, J. y Portela Silva, M. J.: La Casa de Altamira durante el Renacimiento. Estudio introductorio y colección diplomática. Santiago de Compostela, 2003; y PARDO DE GuevarA, E.: Los señores de Galicia. Tenentes y condes de Lemos en la Edad Media, 2 vols. La Coruña, 2000.

13. Eiras Roel, A.: «El señorío gallego...», p. 128.

14. Migués Rodríguez, V. M.: As terras, as pousas e os vinculeiros. A fidalguía galega na Época Moderna. Sada (La Coruña), 2002, pp. 331-335; Presedo Garazo, A.: Dueños y señores de casas, torres y pazos, 1500-1900 (Contribución al estudio de la fidalguía gallega). Santiago de Compostela, 2001, tesis de doctorado inédita, pp. 448-457; Castro Pérez, F.: A Casa de Valladares. Formación e evolución do patrimonio dunha familia dominante na Pontevedra do Antigo Réxime. Pontevedra, 
se trata siempre de análisis parciales, doblemente condicionados, en primer término, por las propias fuentes conservadas en estos fondos, en los que la Casa hidalga ha primado el acopio de documentación referida a la consolidación y conservación de su patrimonio, principalmente territorial ${ }^{15}$; $y$, sobre todo, en segundo término, por las líneas de investigación desarrolladas, que se han centrado, sobre todo, en los mecanismos de consolidación patrimonial, la estructura y evolución de los ingresos, la dinámica de reproducción social y las pautas de consumo de las casas analizadas, en detrimento de otras temáticas ${ }^{16}$.

En las páginas que siguen, nos hemos propuesto elaborar una primera aproximación a este conjunto de hidalgos que tuvieron bajo su control pequeños o muy pequeños señoríos jurisdiccionales, cuando no simplemente un número reducido de vasallos, centrando para ello nuestra atención en el proceso de acceso a los mismos durante el primer tramo de la Edad Moderna -esto es, en una cronología bastante anterior a la de los datos que venimos comentando en esta introducción-. Por tanto, nuestro análisis debe contemplar al menos dos temáticas complementarias: por un lado, los mecanismos de que se valieron aquellos que se convirtieron más tempranamente en señores de vasallos, y por otro, la conflictividad que generó este proceso.

\section{Primera oleada de hidalgos SeÑores de Cotos}

Los datos relativos a la segunda mitad del siglo XviII nos remiten a un punto de llegada que coincide en el tiempo con la culminación de un proceso continuado de fusión patrimonial que se venía produciendo dentro del estamento noble gallego, del cual sacan mayor provecho las casas hidalgas que pertenecen a sus niveles más

2004, pp. 81-90; e Iglesias Blanco, A. S.: A Casa de Xunqueiras nos séculos XVIII e XIX. Contribución ó estudio das economías fidalgas. Valga (Pontevedra), 2004, pp. 66-70 y La Casa de Amarante. Siglos XVI-XIX. Santiago de Compostela, 2008, tesis de doctorado editada en formato digital, pp. 211-214.

15. Para más información sobre los archivos procedentes de casas hidalgas gallegas, vid. GaLLEGO Domínguez, O.: «Os arquivos da nobreza e o seu tratamento arquivístico», en VV. AA.: Conservala memoria. Novas adquisicións da Consellería de Cultura e Xuventude para o Arquivo do Reino de Galicia. La Coruña, 1993, pp. 63-81; Migués Rodríguez, V. M.: Os Arquivos Privados e a Nobreza: un Apuntamento Histórico-Arquivístico. O caso galego a través do fondo do Marquesado de «San Martín» de Ombreiro [ARG]. La Coruña, 2002; VAamonde Gamo, A.: «El archivo de los Vaamonde en la Casa de Ouces», Anuario Brigantino, 18, 1995, pp. 77-82; y VÁzquez Bertomeu, M.: «Escritura y sociedad en la Galicia moderna: reflexiones a propósito del archivo de la casa de Mirapeixe», Estudios Mindonienses, 20, 2004, pp. 893-915.

16. Mención especial merece en este sentido, debido al enfoque que ha primado la relación existente entre la consolidación del patrimonio amayorazgado y el acceso al poder señorial, el ensayo de Díaz-Castroverde Lodeiro, J. L.: El señorio de la Casa de Sonán en su jurisdicción, gobierno $y$ hacienda durante los siglos XVI al XX. Padrón (La Coruña), 1995. 
elevados ${ }^{17}$. El mercado matrimonial, más restrictivo y elitista cuanto mayores sean los privilegios acumulados por la Casa, y la extinción biológica de algunos linajes facilitaron el aglutinamiento de jurisdicciones -de diferentes dimensiones, con un número variado de vasallos y con diversos derechos- pertenecientes en un principio a casas distintas, en torno a una serie reducida de estas. Este proceso de concentración jurisdiccional todavía no ha sido objeto de una investigación en profundidad, pero sabemos que en la centuria dieciochesca no solo condicionó a los medianos señores de vasallos, sino también a aquellas casas que señoreaban pequeñas o muy pequeñas jurisdicciones. Entre los primeros, podemos destacar a doña Joaquina de Oca, señora de la Casa de Bergondo, puesto que cuando en 1787 encarga que se realice un inventario detallado del patrimonio que habían usufructuado ella y su difunto cónyuge, el marqués de Mos, en este figuran 24 cotos dispersos por las actuales provincias de La Coruña, Lugo y Orense, en los cuales residían 924 vasallos -Bergondo- y otros 727 -Mos-a la altura de $1760^{18}$. Por su parte, entre los pequeños o muy pequeños señores jurisdiccionales, y continuando con otras casas que también consiguieron un título nobiliario, podríamos citar a los marqueses de Viance (título concedido en 1628), que asimismo eran señores de las jurisdicciones de Bóveda, Cesar, Goián, Outarelo, Pape, Saa de Páramo y Verea, las cuales apenas suman 86 vasallos en $1760^{19}$; o a don Benito María de Prado, cuyos descendientes portarán el título de marqueses de Ombreiro (a partir de 1817), ya que a fines del siglo XVIII ejerce jurisdicción sobre 35 vasallos $^{20}$.

Sin embargo, la política matrimonial y las estrategias de sucesión ya habían desempeñado un papel relevante mucho antes, no solo en la perpetuación de su patrimonio material y simbólico, sino también cuando algunos hidalgos dieron sus primeros pasos para acceder al señorío. De hecho, el proceso había cristalizado en la Alta Edad Moderna como continuación de la expansión señorial que protagonizaran previamente los principales linajes nobiliarios y las gentes puestas a su servicio en la última centuria medieval ${ }^{21}$. Es entre las primeras casas hidalgas cuyos mayorazgos se

17. Migués Rodríguez, V. M.: As terras, as pousas..., pp. 64-71; y Presedo Garazo, A.: A Fidalguia Galega. Estudos sobre a reprodución social dos fidalgos na Galicia Moderna. Santiago de Compostela, 2008, pp. 123-146.

18. Archivo Histórico Provincial de Orense [en adelante AHPOu], Casas Particulares [en adelante CP], Casa do Castro, Noceda, caja 2. Para el número de vasallos en 1760, vid. Eiras Roel, A.: «El señorío gallego...», tabla 2, p. 132.

19. Archivo de la Casa de Vilarxoán [en adelante ACV], caja 2, n. 61. Para el número de vasallos en 1760, vid. Eiras Roel, op. cit., p. 134.

20. Ibidem.

21. Baz Vicente, M. ${ }^{a}$ J.: Señorío y propiedad foral..., pp. 51-67; Beceiro Pita, I.: El Condado de Benavente en el siglo XV. Benavente, 1998, pp. 35 y ss.; Fernández Suárez, G. F.: La Nobleza Gallega..., pp. 86-95 y 140-142; García Oro, J. y Portela Silva, M. J.: La Casa de Altamira...; y Pardo de Guevara, op. cit. 
fundan antes de 1550, las cuales todavía mantienen lazos estrechos de parentesco y/o de servicio con dichos linajes, donde debemos intentar buscar los primeros hidalgos que ejercen como señores de vasallos, y que se valieron de las estrategias matrimoniales y sucesorias, junto a otros mecanismos como las mercedes, las adquisiciones o la usurpación señorial, a la hora de acceder al señorío jurisdiccional.

Tomando con la debida cautela el Recuento de las Casas Antiguas del Reino de Galicia que redactó Vasco de Aponte en c. 1530-153522, esta obra permite -con el apoyo de fuentes documentales directas- reconstruir la nómina de grandes y principales que se hallaban al servicio de algunas de las casas nobiliarias más poderosas en la Galicia del siglo xv, como las de Ares Pardo das Mariñas y su hijo Goméz Pérez das Mariñas, la de Álvaro Páez de Soutomaior, la de Sancho de Ulloa -I conde de Monterrei- o las de Fernán Pérez de Andrade y su hijo Diego de Andrade ${ }^{23}$. Estos sirvientes señoriales, que mantenían a sus propios escuderos y hombres a caballo, podían disponer de vasallos. Nueve de los diez que sirvieron a Ares Pardo en la primera mitad de la centuria, seis de los ocho que integraron la Casa de Gómez Pérez a mediados de siglo, dos de los cinco que se hallan al servicio de Álvaro Páez en c. 1435-1468, ocho de veintiuno en la Casa de Fernández Pérez en 1435-1470 y uno de veinte en la de su hijo Diego de Andrade en 1470-1490, contaban con vasallos a su cargo. En conjunto, representan un porcentaje nada desdeñable que se sitúa en el 40,6\%, descartando los once que sirven en la Casa del I conde de Monterrei, a ninguno de los cuales reconoce dicho autor la posesión de vasallo alguno; pero conviene no exagerar, ya que lo que abunda, con la excepción de sendas casas de los Mariñas, son los grandes y principales que carecen de ellos, e incluso a medida que nos acercamos al tramo final de la centuria, la tendencia que se desprende de estas seis casas indica un descenso drástico. En la primera mitad, el $90 \%$ de los que se relacionan con la Casa de Ares Pardo das Mariñas habrían tenido vasallos a su cargo; en el tramo central, el 75\% de los de la Casa de Gómez Pérez das Mariñas, el 40\% de los de Álvaro Páez de Soutomaior y el $38 \%$ de los de Fernán Pérez de Andrade; y finalmente, en el último tercio, tan solo un $5 \%$ en la Casa de Diego de Andrade ${ }^{24}$. Es más, solo uno sobre un total de veintiséis -Gómez Pérez «o vello»- figura en dicha obra como señor de Currás,

22. Aponte, Vasco de: Recuento de las Casas Antiguas de Galicia, c. 1530-1535. Edición a cargo de C. Díaz y Díaz et al., Santiago de Compostela, 1986.

23. La nómina de los grandes y principales integrados en las casas de estos cinco magnates bajomedievales puede ser consultada en Presedo Garazo, A.: A Fidalguía Galega..., pp. 43-45.

24. A finales del siglo xv, la reducción que se evidencia en la Casa de Andrade debe ser puesta en relación con las medidas tomadas por los Reyes Católicos de cara a controlar y pacificar a la nobleza gallega, que también afectó, en consecuencia, a los hidalgos que habían servido en las casas de los magnates bajomedievales. Vid. Fernández Vega, L.: La Real Audiencia de Galicia, órgano de gobierno en el Antiguo Régimen (1480-1808). La Coruña, 1982, t. II, pp. 117-120 y 196-203. 
Dorneda y $\mathrm{Oza}^{25}$, mientras que para el resto solo consta que disponen de vasallos, nada más. De todo ello, nos interesa retener al menos tres ideas importantes en relación con la materia que nos ocupa. La primera es que las casas de los poderosos nobles bajomedievales gallegos, a los cuales podríamos añadir algunos señores eclesiásticos, daban cabida a individuos que les servían en el desempeño de tareas diversas ${ }^{26}$. En segundo lugar, algunos de estos servidores, seguramente los más hábiles y mejor relacionados con el jefe de Casa, disponen de vasallos. En tercer lugar, es muy probable que parte de dichos vasallos hayan sido cedidos por parte del señor, junto con las tierras a las que están sujetos, para que velen por sus intereses y sus derechos, de manera análoga a otros casos ya estudiados ${ }^{27}$; o que, simplemente, alguno de estos principales ya pueda disponer de vasallos propios bajo su jurisdicción, como por ejemplo Alonso de Lanzós, quien figura como principal en la Casa de Fernán Pérez de Andrade, con 20 hombres a caballo y 400 vasallos a su cargo según Vasco de Aponte, puesto que recibe el coto de Broño de manos de su suegra doña Leonor de Castro en $1467^{28}$.

Sus trayectorias individuales nos permiten ilustrar el interés que muestran por sentar las bases del patrimonio amayorazgado de sus casas, ya consolidado en la primera mitad del siglo xvi, al que no dudan en incorporar los cotos y vasallos que tienen a su cargo. La mayor parte de sus casas acumulan desde muy pronto grandes cotas de poder, e irán incorporando otras a medida que avancen las centurias modernas, o bien, ellas mismas serán agregadas a otras incluso más poderosas, hasta perfilar una minoría claramente elitista que destaca por encima del resto de los hidalgos gallegos, recibiendo algunas de ellas un título nobiliario en el transcurso del xviI. Su característico modelo de reproducción social y las estrategias empleadas en la consolidación de sus dominios serán imitadas, repetidamente, tanto por los miembros de la propia fidalguía como por los aspirantes a integrarse en ella. No obstante, nuestro interés se centra, en esta ocasión, únicamente en la importancia que tuvo la posesión de estas pequeñas jurisdicciones cuando se asentaron las bases para la temprana constitución de sus mayorazgos, que no habría sido posible sin la adopción de un modelo sucesorio que permitiese consolidar linajes troncales ${ }^{29}$.

25. Aponte, op. cit., p. 151.

26. Presedo Garazo, A.: A Fidalguía Galega..., pp. 21 y ss.

27. Framiñán Santas, A. M. a y García G. Ledo, X. A.: «Os Costela, fidalgos da Casa de Moscoso", Descubrindo DEZA. Anuario de Estudios e Investigación, 6, 2004, pp. 145-167; y PRESEDO Garazo, A.: Nobleza y régimen señorial en Galicia. La Casa Montaos en los siglos XVI y XVII. Santiago de Compostela, 2011, pp. 221-224.

28. Archivo Histórico Diocesano de Santiago, Fondo General, San Martín, leg. 12, n. ${ }^{\circ} 98$, fols. 75v-76r; y APONTE, op. cit., p. 132.

29. Clavero, B.: Mayorazgo. Propiedad feudal en Castilla (1369-1836). Madrid, 1974, pp. 211-214. 
Uno de ellos fue el hidalgo lucense Pedro de Bolaño, hijo de Fernán Díaz de Ribadeneira y yerno del mariscal Pedro Pardo de Cela, que se mueve en la órbita de influencia de la Casa de Andrade y de la del citado I conde de Monterrei y que contribuye a cimentar, en el último cuarto del siglo xv, el patrimonio de algunas de las casas hidalgas más poderosas de la provincia de Lugo, siendo la más importante de estas la de Torés, cuyo dueño consigue el título de marquesado de Puebla de Parga en 1680. En 1488 le cede a su hija doña María de Bolaño el coto de Noceda tras el embargo a que lo había sometido don Diego López de Haro, sentando las bases para la futura consolidación de la Casa de Noceda ${ }^{30}$. En su testamento fechado en $1491^{31}$, mejora a su hijo Fernando con un tercio de sus bienes que se habrá de situar sobre la Casa de Torés con todos los vasallos y rentas de las tierras de Balboa y Cancelada y del coto de Cesar; también deja en herencia a la mayor parte de su prole bienes de naturaleza señorial ${ }^{32}$ : Pedro recibe los vasallos, rentas y derechos que le corresponden en los cotos de A Baleira y Lea y en las tierras de Bacorelle, Freires y Miranda de Rei, Bernardo los vasallos que le pertenecen en el obispado de Mondoñedo, la citada doña María los cotos de Laiosa y Rosende, y doña Isabel el coto de Sindrán «con todo el señorío e vasallaje e rentas del». En 1503, es su hijo mejorado, el señor Fernando Díaz de Ribadeneira, quien ofrece en arras a su mujer doña María de Pimentel el coto de Torés con su jurisdicción y vasallos, como fianza por los 400.000 maravedíes de dote que aquella había aportado a dicho matrimonio ${ }^{33}$; y en el momento de otorgar su testamento en 1514, establece una nueva mejora a favor de su hija doña Beatriz de Castro en la que incluye de nuevo la fortaleza y Casa de Torés junto con la tercera parte de todos sus bienes ${ }^{34}$. Esta última recibe en 1522, en concepto de arras que le ofrece por su desposorio su cónyuge Juan López Pardo de Haro, asimismo hijo del señor Fernán Pérez Parragués y doña Constanza das Mariñas, los cotos de Fonteita y Riomol -cuya jurisdicción civil y criminal comparte con el conde de Lemos y el marqués de Astorga- y las cargas de naturaleza señorial que deben contribuir los vasallos en ellos residentes (luctuosa, portazgo, servicio señorial y demás derechos y serventías $)^{35}$.

Otros tuvieron que sortear ciertas dificultades antes de conseguir incorporar dichas jurisdicciones a sus mayorazgos. Lope de Taboada, cuyo padre de nombre

30. Archivo Histórico Universitario de Santiago [en adelante AHUS], Archivo Ducal de Medinaceli [en adelante ADM], Torés, m. 75, leg. 3, n. ${ }^{\circ}$. $^{\circ}$

31. AHUS, ADM, Torés, m. 80, leg. 5 , n. $^{\circ} 35$.

32. Solo dos de sus hijas representan la excepción y reciben únicamente bienes de naturaleza territorial: a doña Mayor le corresponde la Casa y puerto de Burela con todas sus rentas, y a doña Teresa las rentas en Tierra de Páramo.

33. AHUS, ADM, Torés, m. 72, leg. 1, n. ${ }^{\circ} 55$.

34. AHUS, ADM, Torés, m. 80, leg. 5, n. ${ }^{\circ} 36$.

35. AHUS, ADM, Torés, m. 72, leg. 1, n. $^{\circ} 56$. 
homónimo figura, del mismo modo que Pedro de Bolaño, en la nómina de grandes que habían estado al servicio del I conde de Monterrei, se vio obligado a dividir la Tierra de Taboada en 1512 con su primo, el ex-franciscano Juan Rodríguez de Camba, quien le puso pleito por la parte del patrimonio de la Casa de Taboada que le correspondía por su padre Fernando de Camba, llegando esta causa en grado de apelación hasta la Real Chancillería de Valladolid. Ya anteriormente, los hermanos Lope Taboada y Fernando de Camba, padres de ambos litigantes, habían efectuado un primer reparto de dicho patrimonio -a través de una concordia otorgada en 1463- quienes, a su vez, lo habían recibido de su tío Álvaro Taboada; así que esta partición representó en la práctica una nueva división del patrimonio familiar, previa a la fundación del mayorazgo de la Casa de Taboada por parte del mencionado Lope de Taboada y su mujer doña María de Ulloa, primero en 1522 y nuevamente en $1533^{36}$. Por su parte, el citado Alonso de Lanzós, que había participado activamente en algunos de los episodios políticos más controvertidos en la Galicia de la segunda mitad del siglo xv, deja estipulado en su testamento, otorgado en 1498, que sus cinco hijas, habidas en sus dos matrimonios, hereden en partes iguales sus bienes muebles y raíces, tierras, vasallos y señoríos, con la condición de que falleciendo alguna de ellas en minoría de edad, dicha parte pase a sus hermanas vivas. Será su segunda mujer, doña María de Montaos, procedente del linaje Bermúdez de Castro que porta los derechos sucesorios a la Casa de Montaos, la que en su testamento de 1500 opte por mejorar a su hija doña Inés, casada con Fernando de Andrade, con bienes de naturaleza señorial, al incluir en dicha mejora el coto de San Sadurniño ${ }^{37}$.

Parte de estos cotos, cuyo señorío jurisdiccional intenta patrimonializar este reducido grupo de poderosos linajes hidalgos en los inicios de la Edad Moderna, tiene su origen en pequeñas jurisdicciones sometidas inicialmente a un señor eclesiástico que las había cedido en foro, en feudo o en encomienda, con la intención de garantizar la salvaguarda de sus intereses en un contexto marcado por la violenta expansión patrimonial que venían protagonizando los magnates nobiliarios desde el último cuarto del siglo xiv, entre los cuales figuran los mencionados Mariñas, Soutomaior, Ulloa y Andrade, y que se había tornado asfixiante a mediados del xv. Como ejemplos representativos de la primera de estas tres modalidades de cesión jurisdiccional que realiza el estamento eclesiástico en beneficio de dichos magnates

36. Un estudio pormenorizado de la complicada consolidación del patrimonio de la Casa de Taboada en los inicios de la Edad Moderna, debido a los litigios intrafamiliares que tienen su origen en la concordia de 1463, en Díaz-Castroverde Lodeiro, J. L.: Morgados e xurisdiccións na Terra e condado de Taboada. Séculos XV-XVIII. Guntín (Lugo), 2012, pp. 131 y ss. Parte de las cláusulas del documento fundacional de 1533 se hallan en AHPOu, CP, Casa do Castro, Noceda, Documentos generales, caja 6, n. $^{\circ} 3$.

37. AHUS, Fondos Privados [en adelante FP], Marquesado de Montaos, caja 17, n. ${ }^{\circ} 1$. 
y sus principales, se pueden citar el foro por el cual los citados hermanos Lope de Taboada y Fernando de Camba reciben en 1478 del monasterio cisterciense de Oseira la jurisdicción sobre el coto de Carballedo ${ }^{38}$-provincia de Lugo-; o el foro que otorga en 06/08/1471 el abad del monasterio benedictino de Samos a favor Álvaro González de Ribadeneira (también grande al servicio del I conde de Monterrei), en el que se incluye el coto de Froián -de nuevo en Lugo- con todo su vasallaje, jurisdicción y señorío, que realmente es una renovación del contrato foral que esta misma abadía había suscrito anteriormente a favor del abuelo homónimo de este hidalgo ${ }^{39}$. Por su parte, en relación con la cesión en feudo, es obligado referirse al arzobispo de Santiago, que empleó dicha modalidad con frecuencia a lo largo del siglo xv, combinada con otras fórmulas feudovasalláticas como el préstamo o la terrería, para beneficiar a algunos linajes nobles compostelanos que le ofrecen su apoyo en las constantes contiendas en que este se ve envuelto a lo largo de la centuria, o simplemente con el objeto de establecer alianzas con ellos ${ }^{40}$. Y en cuanto al acceso a bienes eclesiásticos que incluyan el ejercicio jurisdiccional a través del régimen de encomienda, este ha sido documentado, entre otros, para el monasterio cisterciense de Meira ${ }^{41}$ o el cabildo catedralicio de Tui ${ }^{42}$.

Las casas nobles e hidalgas reforzaron su poder sobre los cotos que habían recibido de manos de las instituciones eclesiásticas, por lo que, ante su reiterada desobediencia y abuso, los abades y obispos no dudaron en acudir ante los monarcas para acusarles de usurpación dominial, solicitando el amparo real y reclamando su devolución. En la provincia de Orense, la congregación benedictina de Celanova se quejó del conde de Santa Marta ante Enrique IV en 1462, acusándole de haber ocupado ilícitamente el coto de Rabal ${ }^{43}$. En 1486, el priorato agustino de Xunqueira de Ambía hizo lo propio ante los Reyes Católicos denunciando al conde de Lemos por haberse apropiado de los cotos de Castro de Ferreira y Teixeira, y al conde de Ribadavia por haberle sustraído el coto de Ramuín. También en 1486,

38. Díaz-Castroverde Lodeiro, J. L.: Morgados e xurisdiccións..., pp. 109-110.

39. Doc. edit. por García Oro, J. y Portela Silva, M. J.: «Osorios, Bolaños, Pardos y Ribadeneiras: Las casas nobles lucenses, camino de la Modernidad», Anuario Brigantino, 25, 2002, pp. $169-170$.

40. Rodríguez González, A.: «Documentación Medieval del Archivo Diocesano de Santiago: Libro de feudos de diferentes bienes, feligresías, cotos y jurisdicciones», Compostellanum, XXXVII, 1992, pp. 373-462; Vázquez Bertomeu, M.: La Hacienda Arzobispal Compostelana. Libros de recaudación (1481-83 y 1486-91). Santiago de Compostela, 2002, pp. 59-60; y Presedo Garazo, A.: Nobleza y régimen señorial en Galicia..., pp. 65-76.

41. Mariño Veiras, D.: Señorío de Santa María de Meira (ss. XII-XVI). La Coruña, 1983, pp. 403-404.

42. Sánchez Cabrera, M. ${ }^{a}$ C.: El Bajo Miño en el siglo Xv. El espacio y los hombres. La Coruña, 1997, pp. 257-259.

43. Vaquero Díaz, M. ${ }^{a}$ B.: Colección diplomática do mosteiro de san Salvador de Celanova (ss. XIII-XV). Santiago de Compostela, 2004, t. II (1450-1482), doc. n. ${ }^{\circ}$ 522, pp. 179-180. 
este segundo noble fue denunciado por el monasterio cisterciense de San Clodio, que consideraba que le «tiene entrados» ocho cotos, y por el deán y cabildo de la Iglesia Catedral de Orense, que le acusa de haber tomado el coto de Castrofiz ${ }^{44}$; y asimismo los monarcas ampararon al abad y monjes de Oseira contra algunos caballeros que «contra rasón e derecho los feriran o mataran o lisyaran o tomaran o anpararan los vasallos e renteros e cotos del dicho monasterio» ${ }^{45}$. Por todo ello, cuando en 1489 los Reyes Católicos deciden acometer la reforma del monacato gallego ${ }^{46}$, era habitual que los nobles incluyesen en sus testamentos alguna cláusula en la que pedían perdón por los daños causados a las casas monásticas con motivo de la apropiación indebida de sus bienes ${ }^{47}$. El patrimonio territorial de estas instituciones regulares se fue restituyendo a lo largo del siglo xvi, con más o menos problemas dependiendo de cada caso concreto, pero en lo que concierne a los límites físicos de sus señoríos, estas no siempre consiguieron eludir los efectos provocados por la enorme voracidad nobiliaria bajomedieval ${ }^{48}$.

Ora protagonizasen ellos mismos la usurpación jurisdiccional, ora se beneficiasen de la misma como feudatarios de los magnates, estas primeras casas hidalgas se valieron en parte de dicha vía para hacerse con el control de los cotos que pretenden patrimonializar, dando lugar a litigios con los señores eclesiásticos que se extenderán a lo largo de la primera centuria moderna ${ }^{49}$. Por ejemplo, en la Galicia occidental, las dos ramas linajudas de los Caamaño, que, por un lado, poseen la Casa y señorío de Rubiáns, y, por otro, la Casa de Caamaño, habían

44. Fernández Suárez, G. F.: La Nobleza Gallega..., pp. 216-219.

45. AHPOu, Clero, Oseira, caja 9979, s. n.

46. Fernández Cortizo, C.: «La orden de San Benito en la Galicia de la época moderna: La reforma de la Congregación de Castilla y las visitas generales», en López VÁzQuEz, J. M. (coord.): Opus Monasticorum. Patrimonio, Arte, Historia y Orden. Santiago de Compostela, 2005, pp. 23-41 $\mathrm{y}$ «A regular observancia, quebrada: visita e reforma dos mosteiros galegos dos relixiosos da Orde de San Bieito en tempos dos Reis Católicos», en Fernández Castiñeiras, E. y Monterroso Montero, J. M. (coords.): Opus Monasticorum II. Arte beneditina nos camiños de Santiago. Santiago de Compostela, 2006, pp. 81-109.

47. Presedo Garazo, A.: «Las casas nobles gallegas y su relación con los monasterios de la Diócesis de Santiago de Compostela en la temprana Edad Moderna (1454-1556)», en Casal, R., Andrade, J. M. y López López, R. J. (eds.): Galicia Monástica. Estudos en lembranza da profesora María José Portela Silva. Santiago de Compostela, 2009, pp. 234-235.

48. Burgo López, C.: «El señorío monástico gallego en la Edad Moderna», Obradoiro de Historia Moderna, 1, 1992, pp. 100-101; Eiras Roel, A.: «El señorío gallego...», pp. 122-123; y SAAvedRA FERNÁNDEZ, P.: «Los señoríos de las grandes órdenes monásticas en la Galicia moderna: una visión global», en López Díaz, M. ${ }^{a}$ (ed.): Estudios en homenaje al profesor José M. Pérez García. Vol. 2. Historia y Modernidad. Vigo, 2009, pp. 286-296. Celanova representa la excepción, puesto que logra recuperar en 1486-1487 del conde de Ribadavia los cotos de Bobadela, Macendo y Rabal, y en 1760 forma parte de los diez grandes señores jurisdiccionales gallegos. Vid. Vaquero Díaz, op. cit., t. III (1482-1500), docs. n. ${ }^{\circ} 789$ y 792 a 792-IX, pp. 93-95 y 97-107.

49. Burgo López, C.: art. cit., pp. 102-104. 
recibido en feudo del prelado compostelano, durante el siglo xv, el señorío sobre la villa de Vilagarcía y algunas parroquias adyacentes. Pues bien, estos cotos con sus vasallos y jurisdicción civil y criminal van a ser incluidos en la fundación del mayorazgo de Rubiáns en 1534, dando lugar a un conflicto judicial con el arzobispo de Santiago que se inicia en 1544, en el marco de un proceso de intento de usurpación señorial más amplio en el que dicha mitra, especialmente durante el pontificado de Tavera, se enfrenta con otros linajes nobiliarios de la Tierra de Santiago por el control de ciertas jurisdicciones episcopales ${ }^{50}$. El litigio se resolverá finalmente en 1591, cuando los Caamaño se hacen con la jurisdicción sobre Vilagarcía y las parroquias de Fontecarmoa y Sobradelo, que serán incorporadas posteriormente al marquesado fundado en 1655 , tras haber abonado a cambio 3.116.430 maravedíes $^{51}$.

En la mayor parte de las ocasiones, es la combinación exitosa de estrategias diferentes la que permite que confluyan varios cotos en un mismo individuo, una o dos generaciones previas a que la Casa comience a sentar las bases legales que facilitarán su consolidación patrimonial. Sin ir más lejos, el padre del citado Pedro de Bolaño, Fernán Díaz de Ribadeneira, indica en su testamento de 1461, que le pertenecen 120 vasallos en las pueblas y alfoces de Adai, Neira y San Xiao por merced y donación que le había hecho el conde de Trastámara, que su tía María Fernández de Bolaño le ha vendido los cotos de Damil y Felmil, y que ha recibido el coto de Cerdido como parte de su herencia materna. A mayores, este poderoso hidalgo lugués bajomedieval dispone de los cotos de Baleira, Cedrón, Fonteita, Lea, Mirandela, Riomol, Rosende, Saiáns, Toirán, Val de Láncara, Vilanova, Laiosa y Sindrán, estos dos últimos gravados con una pensión anual de 500 maravedíes que se deben pagar al cabildo de la Catedral de Lugo, junto con sus vasallos en las tierras de Balboa, Cancelada, Ribademiño y Saavedra, situando sobre los portazgos de la Tierra de Balboa los 3.000 maravedíes pares de blancas anuales que se han de pagar, a partes iguales, a los dos conventos de San Francisco y Santo Domingo de la ciudad de Lugo, y a cuyo pago estarán obligados los señores de la Casa de Torés ${ }^{52}$.

En definitiva, las pocas y elitistas casas hidalgas cuyos linajes hunden sus raíces en la Galicia bajomedieval y fundan sus mayorazgos en las décadas iniciales del siglo xvi, han accedido al señorío antes de la llegada del Quinientos, a medida que se impone la lógica de Casa, valiéndose para ello de las mercedes -incluidas,

50. Olivera Serrano, C.: «La Galicia de Vasco de Aponte: los pleitos del arzobispo Tabera contra los linajes de la Tierra de Santiago», En la España Medieval, 22, 1999, pp. 285-315.

51. Bouza-Brey Trillo, F.: El señorio de Villagarcía desde su fundación hasta su marquesado (1461-1655). Santiago de Compostela, 1965, pp. 51 y ss.

52. AHUS, ADM, Torés, m. 80, leg. 5, n. ${ }^{\circ} 35$. 
claro está, las que conceden los monarcas ${ }^{53}$-, la usurpación jurisdiccional, las adquisiciones y las estrategias familiares ${ }^{54}$. Llegado el caso, no dudarán en recurrir a la vía judicial si ven cuestionada su titularidad sobre algunas de estas pequeñas jurisdicciones, no solo contra señores eclesiásticos, sino también contra otros señores seculares, para salvaguardar su posición social privilegiada asociada al ejercicio del poder señorial ${ }^{55}$.

\section{Segunda y decisiva oleada: El «ASAlto a la CAPtura de un SEÑorío»}

A medida que fue avanzando la primera centuria moderna, otros sectores sociales no necesariamente relacionados con estas casas hidalgas de mayor antigüedad iniciaron su ascenso a la fidalguía, contribuyendo a perfilar la característica composición heterogénea de este predominante sector nobiliario gallego. Fue entonces cuando algunos de sus nuevos integrantes protagonizaron el decisivo «asalto a la captura de un señorío» ${ }^{56}$, en un contexto marcado por las continuas necesidades hacendísticas de la monarquía, que propiciaron las desmembraciones jurisdiccionales que se suceden a lo largo del siglo xvi, afectando primero a las órdenes militares en 1529, luego a los monasterios y conventos en 1551 (Bula de Julio III), y en último término a todos los vasallos eclesiásticos, incluidas las mitras catedralicias, en 1574 (Bula de Gregorio XIII) ${ }^{57}$. Una vez más, debemos ver a estos compradores de señoríos como parte de una minoría que busca en dichas transacciones

53. Un caso que se puede citar al respecto es el de los Noguerol de la Casa de Amarante, que habían servido en la Casa de Diego de Andrade y acceden al señorío sobre la Tierra de Reboredo a través de esta vía, y cuyo mayorazgo data de 1511. Vid. Iglesias Blanco, A. S.: La Casa de Amarante..., pp. 41 y ss.

54. No se trata de una manera de actuar exclusiva de estas casas hidalgas gallegas. El patrimonio señorial del asturiano marquesado de Valdecarzana también se constituyó a partir de la usurpación jurisdiccional, el mercado matrimonial y la vía judicial. Cfr. Díaz Álvarez, J.: «Los marqueses de Valdecarzana, señores de vasallos en la Asturias del Antiguo Régimen (siglos XVI-XVIII)», Revista de Historia Moderna, 24, 2006, pp. 376-377.

55. Domínguez Ortiz, A.: Las clases privilegiadas en el Antigno Régimen. Madrid, 1973, pp. 57-58.

56. Expresión acuñada por López DíAz, M.a.: «Alteraciones en el mapa jurisdiccional gallego durante la Edad Moderna: las desmembraciones eclesiásticas del siglo XvI», Estudios Mindonienses, 7, 1991, p. 581.

57. Burgo López, C.: art. cit., pp. 104-107; Faya Díaz, M. ${ }^{a}$ A.: «Los señoríos eclesiásticos gallegos y la venta de jurisdicciones en tiempos de Felipe II», en Pereira Iglesias, J. L. y González Beltrán, J. M. ${ }^{a}$ (eds.): Felipe II y su tiempo. Cádiz, 1999, pp. 101-115; García Oro, J. y Portela Silva, M. ${ }^{\text {J J.: } ~ « E l ~ s e n ̃ o r i ́ o ~ e c l e s i a ́ s t i c o ~ g a l l e g o ~ y ~ l a ~ C o r o n a ~ e n ~ e l ~ s i g l o ~ X V I », ~ E s t u d i o s ~ M i n d o n i e n s e s, ~}$ 17, 2001, pp. 13-275; Guilarte, A. M. ${ }^{\text {a }}$ El Régimen señorial..., pp. 64 y ss.; López Díaz, M. ${ }^{a}$ : «Alteraciones en el mapa jurisdiccional...»; Moxó, S. de: «Las desamortizaciones eclesiásticas del siglo XVI», Anuario de Historia del Derecho Español, XXXI, 1961, pp. 327-361; y SaAvedra FernándeZ, P.: «Contribución al estudio...», pp. 114 y ss. 
una inversión interesada en capital simbólico. En este asalto participan las familias hidalgas vinculadas a los resortes del poder local y a la jerarquía eclesiástica de los núcleos urbanos ${ }^{58}$, entre las cuales figura la compostelana doña María de Neira, quien adquiere en 1586 el lugar y el coto de Oca, en el valle del río Ulla, en donde se construirá con el tiempo el emblemático pazo que lleva este mismo nombre, a cambio de 195.775 maravedíes ${ }^{59}$; y también hacen acto de presencia las familias de poderosos rurales, como los Balboa y Belón, que compran conjuntamente antes de 1563 el coto de Vilarxoán, en O Incio, perteneciente en su origen a la abadía de Samos, por precio de 68.000 maravedíes ${ }^{60}$.

Junto a ellos, también figuran los descendientes de los fundadores de las casas hidalgas de origen bajomedieval adquiriendo igualmente estas jurisdicciones eclesiásticas puestas en venta por la Corona, tal como acredita Lope Taboada Cadórniga, a quien pertenece por entonces la Casa de Taboada, puesto que en 1592 adquiere los dos cotos de San Martiño e Ider, procedentes del dominio jurisdiccional del obispo de Lugo, a cambio de 560 maravedíes $^{61}$.

El poder creciente de estos individuos que se hallan inmersos en pleno ascenso social se extiende, además, a algunos pequeños señores seculares que se vieron obligados a desprenderse de sus cotos condicionados por una coyuntura adversa y la falta de liquidez. Así, en 1549, tras haber enviudado de Álvaro de Aguiar, Guiomar Rodríguez da Barreira tuvo que vender a Fernando Rodríguez de Penelas, escribano en la villa de Castro de Rei, «toda la parte que he y tengo de jurisdiçión, señorío e vasalaje, ansí çevil como cremynal mero mysto imperio» en los cotos de Barreiros, Donalbai y Sesmonde, sitos en la Tierra de Gaioso, y en el de Vilalvite, a cambio de 484 maravedíes $^{62}$. Poco después, este mismo escribano venderá la jurisdicción sobre dichos cuatro cotos a Juan Sanxurxo Aguiar, a partir de quien pasará a formar parte del patrimonio de la Casa de los Neira, asentados en la ciudad de Lugo ${ }^{63}$.

Otras casas hidalgas que también inician su andadura avanzado el Quinientos, incluso llegaron a recibir de manos de un gran noble alguna pequeña jurisdicción en concepto de merced, si bien no es posible establecer una correlación con lo ya expuesto al referirnos a los hidalgos integrados en las casas de los magnates bajomedievales. Dos casos documentados en la provincia de Orense para el segundo

58. López DíAz, M.a: «Alteraciones en el mapa jurisdiccional...», p. 581.

59. López, P.: «Historia del Pazo de Oca», Boletín Auriense, XIV-XV, 1986, p. 152; e Iglesias Blanco, A. S.: La Casa de Amarante..., pp. 108-109.

60. ACV, caja 1, n. $^{\circ} 10,20,23$ y 41.

61. Díaz-Castroverde Lodeiro, J. L.: Morgados e xurisdiccións..., pp. 214-215.

62. Archivo de la Casa de Mirapeixe, Sta. Mariña da Ponte de Rábade, caja 1, n. ${ }^{\circ}$. Se trata de una fotocopia del documento original.

63. Migués Rodríguez, V. M.: As terras, as pousas..., pp. 75-77 y 333. 
cuarto del siglo XviI coinciden en el hecho de que el hidalgo beneficiado con la merced se convierte en señor jurisdiccional después de que él, o bien alguno de sus ascendientes próximos, hayan servido diligentemente al noble otorgante o al Rey, y de que sus casas de procedencia cuenten con un capital simbólico de consideración en las comarcas en que se asienta su solar originario, acumulado generación tras generación en el transcurso de la primera centuria moderna ${ }^{64}$. En ambos, la cesión señorial que implica la merced nobiliaria se traduce en una relación contractual que obliga a los beneficiarios a efectuar el pago de una renta anual para poder ser reconocidos como señores jurisdiccionales.

El primero de ellos es la merced que le concede en 30/06/1634 el VIII conde de Lemos a don Pedro Fernández de Boán, señor de la Casa de san Damián, en Amoeiro, por la cual el beneficiado recibe los cotos y vasallaje de Fontefría, Loureiro y Rouzós, a cambio de 4 fanegas de trigo y otras 31,9 de centeno y 23 cañados de vino tinto y 6 moios de blanco anuales. Previamente, don Pedro le había entregado 400 escudos de oro «quando se offreció el yr a la defenssa de las costas y puertos de mar deste Reyno por la armada de nuestros enemigos yngleses y holandeses y franceses que arrimaron en ellos, para que assimismo me llamó para su camarada»; así que si el citado conde decidía revocar el contrato por impago de dicha renta u otro motivo, debería efectuar necesariamente el reembolso de esa cantidad ${ }^{65}$. El segundo es la merced que le concede el conde de Ribadavia en 18/04/1645, en este caso a través de un contrato de foro, a don Diego de Prada, por la cual este recibe la jurisdicción civil y criminal del coto de Outarelo -Barco de Valdeorras-, estando obligado a pagar un escudo de oro al año. Nuevamente, el noble realiza la cesión en recompensa por «los muchos servicios que él y sus sucesores me an echo y a los señores de mi Casa»; asimismo, don Diego era el primer usufructuario del mayorazgo fundado por su tío don Andrés de Prada en 1611 sobre el solar de la casa de Outarelo, quien, a su vez, había desempeñado el cargo de secretario de los consejos de Estado y de Guerra al servicio de los monarcas Felipe II y Felipe III ${ }^{66}$.

64. O. Gallego Domínguez ha documentado una merced nobiliaria semejante posterior, fechada en 13/06/1707, a favor del dueño de la Casa de Viloira, en el Barco de Valdeorras, Orense. Vid. «Mercedes de los condes de Ribadavia a dos hidalgos de la jurisdicción de Valdeorras», Boletín Avriense, XXXI, 2001, pp. 136-139.

65. AHPOu, CP, Boán, lib. 43, fols. 70v-71r. Vid. los estudios sobre esta familia hidalga orensana que debemos a Ferro Couselo, X.: «Gente llana con ventura. Los Boanes», Boletín Avriense, II, 1972, pp. 7-73; y Rionegro Fariña, I.: «Una familia de poder de la élite orensana: los Boán», en López Díaz, M. ${ }^{a}$ (ed.): Cuadernos Feijonianos de Historia Moderna IV. Santiago de Compostela, 2013, pp. 107-127.

66. Vid. Gallego Domínguez, O.: «Mercedes de los condes de Ribadavia...», pp. 132-136; y García Tato, I.: Vilanova, Outarelo y San Francisco Blanco. Monografía histórica de una parroquia gallega. Barco de Valdeorras (Orense), 1999, pp. 71 y ss. en relación con el origen de esta casa hidalga orensana y su posterior evolución histórica. 


\section{Conflictividad generada por el acceso al señorío}

El acceso al poder señorial por parte de esta reducida serie de casas hidalgas a comienzos de la Época Moderna no estuvo en modo alguno exento de controversia. De hecho, se produjeron litigios intrafamiliares originados por la posesión de los derechos sucesorios sobre estos pequeños señoríos, toda vez que, como hemos comprobado, en ocasiones se trata de bienes recientemente adquiridos. Los mencionados Balboa y Belón que habían adquirido el coto de Vilarxoán representan un ejemplo apropiado al respecto ${ }^{67}$. Diego Belón, heredero de Gil González de Balboa, pretendía que se le reconociese como único señor dentro de los límites de esta pequeña jurisdicción luguesa, mientras que su tío Juan González de Balboa reclamaba igualmente para sí el mismo reconocimiento. Este último se casara con Inés Ares de Balboa, cuyo padre -Alfonso Núñez de Cedrón- también había adquirido parte del coto por venta judicial a cambio de 200 ducados. El matrimonio en cuestión había sido pactado de conveniencia para concentrar las distintas porciones del coto adquiridas por cada una de estas dos familias, y que recayese de una sola pieza en un único heredero, que debía ser Diego Belón. Así, Lope Núñez de Balboa, hijo de Alfonso Núñez, ya le había donado a Diego la parte que le correspondía por su legítima ${ }^{68}$; pero Inés y Juan -ambos tíos de Diegose resistían a dar el paso decisivo en este sentido. Tras una concordia concertada en 1563, donan a favor de su sobrino la parte del señorío que les corresponde, de tal suerte que este y su descendencia habrán de disfrutar a partir de entonces del ejercicio jurisdiccional sobre el coto, comprometiéndose, a cambio, al pago de dos fanegas anuales de centeno. En 1565 figura como único señor de Vilarxoán, y su hijo Diego Sánchez Taboada funda el mayorazgo de esta Casa en 1648, en el que se incluye la jurisdicción sobre este pequeño coto $^{69}$.

Sin salir de la provincia lucense, en Pedradita do Cebreiro, Gonzalo de Armesto y su mujer doña Ana de Valcárcel, dueños de la Casa y señorío de Pacios de Lousada, cedieron en 1595 el derecho que le correspondía a ella, heredado de su abuelo Men Saco de Armesto y transmitido a través de su madre, sobre la jurisdicción y vasallos de los cotos de Pacios, Lousada, O Seixo y Pontealor, a favor de su primo Lope Saco de Armesto, casado con Ana García de Guitián, residentes en la villa de Monforte de Lemos, en una concordia que daba fin a un pleito que había llegado hasta la Real Audiencia de Galicia y en la que se ratifica el pago de 187.000 maravedíes que este les había ofrecido a cambio de dichas jurisdicciones ${ }^{70}$.

67. ACV, caja 1, n. $^{\circ} 10,20$ y 23.

68. ACV, caja 1, n. ${ }^{\circ} 41$.

69. ACV, caja 1, n. $^{\circ} 13$ y 42.

70. Archivo de la Casa y señorío de Pacios de Lousada, documento sin catalogar. Expresamos nuestro agradecimiento a G. F. Fernández Suárez por habernos facilitado una copia del mismo. 
Las casas hidalgas de mayor antigüedad tampoco fueron ajenas a este tipo de disputas, tal como ya hemos visto páginas atrás en relación con la Casa de Taboada. También en Lugo, fue en 1619 cuando don Pedro de Ulloa y Ribadeneira, señor de Noceda, se vio obligado a litigar contra su pariente don Pedro Bolaño y Ribadeneira, asimismo señor de Torés, Parga y Xunqueiras, porque este pretendía que se verificase si la jurisdicción de Noceda pertenecía realmente a los bienes vinculares de los Ulloa Ribadeneira ${ }^{71}$. Aunque la causa se resolvió favorablemente a sus intereses, el heredero de don Pedro, su hermano don Diego de Ulloa y Ribadeneira, no dudó en fundar en 1645 una nueva mejora vincular con todos los bienes muebles y raíces que había adquirido y heredado de sus padres y hermanos; a la que siguió otra mejora con gravamen de vínculo otorgada en 1661 por su viuda, doña Beatriz de Castro Pimentel, en la que incluye el coto de Castrelo ${ }^{72}$.

No obstante, hubo ocasiones en que estos cotos hidalgos fueron objeto de división entre los posibles herederos antes de que se produjese su incorporación a un mayorazgo. Continuando en la provincia luguesa, el coto de Val de Láncara fue repartido en 1592 entre los doce herederos de la última señora que lo había señoreado de una sola pieza y que había muerto antes de dicha fecha sin otorgar testamento ${ }^{73}$. Por otra parte, en 1604 se efectúa la partija de la herencia conjunta de Pedro Fernández de Pallares y su mujer María Vázquez de Baamonde, vecinos de la villa de Sarria y señores del coto de Cesar, entre sus dos únicos hijos: el licenciado Antonio y don Andrés -maestrescuela en la catedral de Lugo-, para efectuar el pago de la mejora vincular que habían otorgado a favor del primero. En uno de los capítulos contractuales que incluye el documento, se especifica que la jurisdicción, pechos y derechos del coto deberán ser repartidos en dos cupos que se habrán de entregar a cada uno de ambos hijos ${ }^{74}$.

La apropiación jurisdiccional que protagonizaron los pequeños o muy pequeños señores seculares fue, por tanto, un proceso que implicó de manera distinta a sus protagonistas. Mientras que unas casas hidalgas incorporan a sus mayorazgos y a una única línea sucesoria los señoríos adquiridos en el transcurso del siglo Xvi y la primera mitad del xviI, o-las menos- que las han recibido de sus antepasados bajomedievales; otras se decantan por repartirlos entre sus herederos o simplemente

71. AHPOu, CP, Casa do Castro, Noceda, Documentos generales, caja 6, n. ${ }^{\circ} 3$.

72. AHPOu, CP, Casa do Castro, Noceda, Genealogía, caja 5, n. ${ }^{\circ} 8$ y 9.

73. Archivo Histórico del Reino de Galicia [en adelante AHRG], Real Audiencia [en adelante RA], Vecinos, leg. 26402/15. Se trata del mismo coto de Val de Láncara que aparece citado en el testamento del hidalgo Fernán Díaz de Ribadeneira, fechado en 1461, al que ya nos hemos referido. Este se lo deja en herencia a su hijo mejorado Fernando, hermano de Pedro de Bolaño, junto con los otros cotos de Toirán, Saiáns, Vilanova, Laiosa, Sindrán, Cedrón y Rosende. AHUS, ADM, Torés, m. 80 , leg. 5 , n. ${ }^{\circ} 35$.

74. ACV, caja 5, n. $^{\circ} 289$. 
se ven obligadas a desprenderse de ellos ante la falta de liquidez. Esta diversidad de comportamiento no fue un obstáculo para que sus cotos formasen parte del patrimonio inmaterial de sus casas, con un fuerte componente simbólico implícito ${ }^{75}$. Su adquisición y posterior conservación debe ser puesta en relación con intereses sociales y políticos que se conjugan en el ámbito local para contribuir al reforzamiento del poder del que son depositarios algunos segundones y sirvientes de los linajes bajomedievales, que ven cómo, a medida que avanza el siglo xvi, otros notables locales, procedentes de otros sectores sociales, también aspiran a ennoblecerse para compartir su mismo horizonte estamental ${ }^{76}$.

De hecho, es muy probable que un objetivo común a todos ellos, al margen de la mayor o menor antigüedad de sus casas y de los diversos mecanismos de que se valieron para acceder al señorío, consistiese en la mera conservación de estos cotos en torno al linaje troncal que portaba los derechos sucesorios; no solo como parte de las estrategias desplegadas para conseguir el reforzamiento de estatus, sino también para disfrutar y ejercer el poder que como tales señores jurisdiccionales les correspondía en el ámbito local por su condición señorial, por modesta que fuese la extensión comprendida por su señorío o por reducido que fuese el número de vasallos que estas pequeñas jurisdicciones podían llegar a comprender. $\mathrm{O}$, si se prefiere, visto desde otra perspectiva a través de un caso concreto: pese a la última división que experimenta el patrimonio originario de la Casa de Taboada en 1547, motivada a raíz de la disputa interfamiliar que ya hemos comentado, los 146 vasallos que poseía en sus doce cotos de la Tierra de Taboada en 1558, representaban mucho más que los 53.108 maravedíes que estos mismos aportaban ese año en concepto de servicio señorial ${ }^{77}$. De ahí que, además de los conflictos que tenían su origen en las fracturas que se podían llegar a generar dentro del propio linaje, no dudasen en litigar contra otros señores, incluso más poderosos, por conservar la titularidad sobre sus señoríos (caso del litigio ya citado entre los Caamaño de Rubiáns contra el arzobispo de Santiago en 1544-1591, o de la Casa de Goiáns contra este mismo prelado en 1572, 1575 y $1578^{78}$ ). Fijémonos brevemente en la controversia legal a que dio lugar la titularidad de los cotos de Gondomar, Vinciós y Val de Louriña, a la que accede una rama segundona de los Sarmiento en el tramo central del siglo xvi, enfrentándose por ello a otra casa noble, la de Montaos. Don Fernando

75. Presedo Garazo, A.: «La imagen del poder de los hidalgos gallegos en la Época Moderna», Obradoiro de Historia Moderna, 20, 2011, pp. 242-243.

76. Cfr. para el acceso al señorío y a las propiedades rústicas de los sectores más aventajados de la burguesía en la Francia del siglo xvi, movidos por su deseo de ennoblecimiento, Huppert, G.: Bourgeois et gentilshommes. La réussite sociale en France au Xvie siècle. París, 1983, pp. 61 y ss.

77. La cantidad procedente del servicio señorial la hemos calculado a partir de los datos que ofrece Díaz-Castroverde Lodeiro, J. L.: Morgados e xurisdiccións..., p. 177.

78. Vázquez Lijó, J. M.: Luces sobre a Casa de Goiáns no Antigo Réxime. Boiro (La Coruña), 2012, p. 32. 
Bermúdez de Castro II había concertado en 1555 un primer compromiso con don García Sarmiento y Soutomaior, por el cual el primero se reservaba para sí dos terceras partes de la jurisdicción sobre estas demarcaciones, al que siguió un censo que este segundo le concedió en 1567 por un principal de dos millones de maravedíes, cuyos réditos se habrían de cobrar a partir de las rentas fijadas sobre estos tres cotos. En 1572 se inicia el litigio entre ambas casas por el control de estas jurisdicciones que se habrá de prolongar hasta 1650, años después de que ambas casas consigan sus respectivos títulos nobiliarios (Gondomar el condado en 1617 y Montaos el marquesado en 1626), del que saldrán beneficiados los Sarmiento Acuña ${ }^{79}$.

Obviamente, las comunidades rurales no asistieron impasibles a este proceso de señorialización. Podemos aproximarnos a la contestación vasallática a que dio lugar el incremento del poder señorial de estos hidalgos a través de los fondos judiciales de la Real Audiencia de Galicia, en los cuales ha quedado constancia de la perspectiva de los vasallos -acallada en cambio en los archivos nobiliarios-, para quienes sus pequeños señores jurisdiccionales cometieron no pocos abusos. La posibilidad que ofrecía este tribunal real de apelar en segunda instancia una sentencia desfavorable dictada previamente en primera por parte de la justicia señorial, o incluso la alternativa de acudir directamente a litigar en primera instancia una causa contra un señor jurisdiccional ${ }^{80}$, animó a algunas comunidades rurales a dar el paso de presentar aquí sus querellas contra sus señores jurisdiccionales, permitiéndonos conocer cuáles fueron los abusos que estas denunciaron haber sufrido por parte de aquellos ${ }^{81}$. Una somera exposición de los motivos que justifican las querellas presentadas por los vasallos de los cotos que señorearon los descendientes del hidalgo lucense Pedro de Bolaño, nos ha permitido constatar cómo el proceso de señorialización también afectó a quienes residían dentro de los límites comprendidos por estas pequeñas jurisdicciones.

Entre los abusos que alegan haber recibido los vecinos del coto de Noceda de su señor, don Álvaro Taboada de Bolaño, cuando se querellan contra este en 28/01/1581, figuran los excesos cometidos por el merino señorial, puesto que les obligara a guardar los presos en la cárcel a su costa, y asimismo se había valido de su autoridad para prenderles indebidamente «por dar ganançia a su s[e]nor».

79. AHUS, FP, Marquesado de Montaos, caja 1, n. $^{\circ} 8$; caja 3 , n. ${ }^{\circ} 23$ y 24 ; y caja 6, n. ${ }^{\circ} 5$ y 6 . Vid. complementariamente García Oro, J.: Don Diego Sarmiento de Acuña, conde de Gondomar y embajador de España (1567-1626). Santiago de Compostela, 1997, pp. 31-33.

80. Fernández Vega, L.: La Real Audiencia de Galicia..., t. II, pp. 120-124; y López Díaz, M. ${ }^{a}$ Señorío y Municipalidad ..., pp. 261-267 y «La administración de la justicia señorial...», pp. 572-573.

81. SAAvedra Fernández, P.: «Los montes abiertos y los concejos rurales en Galicia en los siglos XVI-XVIII: aproximación a un problema», Cuadernos de Estudios Gallegos, 98, 1982, pp. 216-228. 
Los querellantes también denuncian que don Álvaro había realizado modificaciones arbitrarias en el padrón elaborado por el concejo local con motivo del repartimiento del servicio real. Y en tercer lugar que aquel, valiéndose de los poderes jurisdiccionales que le corresponden por su condición de señor, se había propasado en la utilización de los recursos comunales, al extraer madera de los montes y dehesas de los vasallos, impidiéndoles además que lo hiciesen ellos mismos; $y$ ponerles trabas a la hora de acceder al agua que necesitaban para hacer funcionar sus molinos fluviales ${ }^{82}$. Poco después, en 1585 , los vecinos del coto de Baleira también iniciaron otra causa por motivos similares contra su señora, doña María Pimentel, a quien pertenecía además el coto de Riomol, puesto que esta, contraviniendo una concordia pactada anteriormente con sus vasallos, se había aprovechado de su condición señorial para prohibirles talar árboles en un monte comunal, llegando incluso a apresar por tal motivo a más de una veintena de porcioneros de dicho monte ${ }^{83}$. Por su parte, los vecinos del coto de Val de Láncara se quejaban en 1592 de que el reparto de esta pequeña jurisdicción entre los doce herederos de la última señora que lo había poseído de una sola pieza, había traído consigo mucha confusión en el ejercicio de la justicia ordinaria, de tal suerte que no había orden en el gobierno local, hasta el extremo de que dos de los merinos que actuaban en él incluso se propasaran en sacar a algún vecino para apresarlo en otro coto distinto ${ }^{84}$.

Fueron, no obstante, el señor del coto de Torés, solar de los Bolaño, junto con sus oficiales señoriales, quienes protagonizaron los abusos más ruidosos a lo largo de la etapa histórica que comprende nuestro estudio, según se desprende de las demandas presentadas en su contra ante la Real Audiencia de Galicia. Los propios vasallos del coto se quejaban en 1615 de que les ponía trabas para que se reuniese el concejo local, empleando fuerza y violencia para impedir el nombramiento del procurador general del mismo, dando pruebas de «ser xente que tiene por viçio y costunbre destimar en poco las provisiones de esta Real Audiencia». Las querellas en su contra fueron interpuestas incluso por los vecinos de otras jurisdicciones. Primero en 1609 por parte de los vasallos del coto de Biduedo, perteneciente al monasterio benedictino de Samos, que se quejaban entonces del juez de Torés y sus alguaciles por el apresamiento de ciertas reses en sus montes comunales, e impedirles la tala de árboles y el regadío de sus prados y heredades si antes no pagaban ciertas prendas. En 1618, les tocó el turno a los vecinos del concejo de Ribeira de Agueira, cuyas quejas contra don Pedro Bolaño y Ribadeneira representan un buen ejemplo de la señorialización que pusieron en práctica algunos de estos

82. AHRG, RA, Vecinos, leg. 1182/7.

83. AHRG, RA, Vecinos, leg. 3291/30.

84. AHRG, RA, Vecinos, leg. 26402/15. 
hidalgos que se hacen con el control de pequeñas jurisdicciones. Además de los ya mencionados excesos relacionados con la tala de árboles en los montes comunales, el merino de Torés ha abusado del ejercicio de su cargo señorial, causándoles muchas molestias al obligarles al reparo de caminos e impedirles la pesca de truchas en los ríos. En este caso, los agravios también competen al ejercicio de la justicia señorial: si anteriormente eran oídos en audiencia en la villa de As Nogais, donde se les había fijado la cárcel señorial, ahora se les ha impuesto para ambos cometidos la localidad de Torés. A mayores, los querellantes solicitan que el «dicho merino, escrivanos y más ministros de justicia de la jurisdicción del dicho don Pedro, en el cobrar de sus derechos guarden el arancel real de Su Magestad y no hesçedan dello», y que además sean residenciados de sus oficios ${ }^{85}$.

Pese a que se trata de casos concretos referidos a hidalgos que ejercen como señores jurisdiccionales entre finales del siglo xvi e inicios del xvII, y que comparten una genealogía común, son una prueba suficientemente evidente de que la conflictividad generada por el acceso al señorío no solo implicó, a un mismo nivel, a los propios señores, sino también en sentido vertical a sus vasallos.

\section{Conclusiones}

El acceso al señorío que protagonizan las casas hidalgas gallegas durante el siglo xvi y la primera mitad del xvir fue obra de una minoría que se consolidó dentro de este sector nobiliario. Inicialmente destacaron en este grupo acotado aquellas que ya habían sido capaces de lograr este objetivo en el contexto de la Galicia bajomedieval. Se trata de hidalgos que habían estado al servicio de los señores jurisdiccionales más importantes durante el xv, tanto laicos (por ejemplo, los citados Pedro de Bolaño y Lope de Taboada que habían servido al I conde de Monterrei), como eclesiásticos (véanse los dos linajes hidalgos también citados de Bermúdez de Castro y Caamaño que sirvieron al arzobispo de Santiago), quienes están consolidando las bases de sus importantes patrimonios a medida que adoptan la dinámica de Casa, imitando para ello el modelo reproductivo puesto en práctica por las poderosas casas condales tardomedievales. Las relaciones de parentesco con algunos de dichos señores y los méritos generados en el correcto desempeño de su servicio allanarán el camino para que estos consigan hacerse con la jurisdicción sobre pequeñas parcelas de territorio, como merced que le conceden aquellos y que suele materializarse a través de una cesión en foro, en feudo o en encomienda. Asimismo, de manera complementaria en

85. AHRG, RA, Vecinos, legs. 8249/16, 8274/6 y 9760/26. Son evidentes las semejanzas que se observan con los agravios cometidos por la familia Ruiz de Alarcón, señores de Almodóvar del Pinar, sobre los vasallos de dicho señorío. Vid. López-SALAzar Pérez, J.: «El espejo del mal señor. El señorío de Almodóvar del Pinar durante el siglo xvi», Cuadernos de Historia Moderna, 16, 1995, pp. 277-291. 
algunas ocasiones, aunque también principal en otras, se valen de otros mecanismos de acceso como las mercedes reales, la adquisición de cotos a otros señores, el mercado matrimonial -como hemos tenido ocasión de comprobar con detalle a partir de la Casa de Torés- y la usurpación señorial a instituciones eclesiásticas, sobre todo al clero regular. La combinación de estos mecanismos será decisiva para que las casas hidalgas de origen bajomedieval consigan acceder al señorío. Cuando a inicios del Quinientos comiencen a fundar sus mayorazgos, el proceso de patrimonialización de sus pequeñas jurisdicciones ya era una realidad dada, como se desprende del hecho de que intenten su amortización como parte del patrimonio amayorazgado y que dicho propósito derive en disputas legales con otros señores, generalmente eclesiásticos, que denuncian haber sido objeto de usurpación por parte de estos.

Conforme vaya avanzando el siglo xvi, otros sectores de la sociedad gallega que han logrado acceder a cotas de poder en el ámbito local, tanto rural (familia Balboa y Belón de Vilarxoán o familia Armesto de Pacios de Lousada) como urbano (doña María de Neira, de Santiago de Compostela, o la Casa de los Neira de Lugo), y que aspiran al ennoblecimiento como colofón lógico para coronar su exitoso ascenso social, van a intentar seguir un rumbo parejo. Una vez más nos hallamos ante una minoría elitista que adopta un idéntico modelo de reproducción social que se articula en torno al mayorazgo y la dinámica de Casa, y cuyos integrantes aspiran a hacerse con pequeños señoríos. De nuevo estos también adquieren cotos pertenecientes a otros pequeños señores jurisdiccionales que claramente se ven apremiados ante la falta de liquidez. Ahora bien, a diferencia de los precedentes, se decantan por las desmembraciones de las jurisdicciones eclesiásticas que propicia la Corona en el transcurso de la centuria $(1529,1551$ y 1574), a lo cual no dudan en apuntarse igualmente, con el mismo propósito de sacar provecho, algunas casas de origen bajomedieval, como Taboada. Además, nos los encontramos accediendo a estos pequeños señoríos tras recibirlos de manos de importantes nobles con solar en Galicia que han participado en las empresas políticas de la Monarquía, a los cuales han servido diligentemente, como atestiguan para el segundo cuarto del siglo XVII las dos casas orensanas de San Damián (familia Boán) y Outarelo (familia Prada).

Unos y otros comparten una característica común: la posesión de estas pequeñas o muy pequeñas jurisdicciones les permite detentar un gran poder sobre los vasallos que residen en aquellas localidades sometidas a su señorío jurisdiccional; de ahí que también compartan un objetivo común: patrimonializar estos señoríos incorporándolos a sus mayorazgos. Siendo preciso, ambos sectores no dudarán en acudir a la vía judicial para alcanzar su objetivo, dando lugar a litigios contra otros señores jurisdiccionales, incluso más poderosos, tanto eclesiásticos -principalmentecomo seculares, cuya resolución suele prolongarse en el tiempo durante varias décadas (recuérdese la disputa que mantiene el arzobispo de Santiago con la casa de Rubiáns entre 1544 y 1591; o la de los Bermúdez de Castro con los Sarmiento de 
Acuña entre 1572 y 1650). No obstante, en este tramo inicial de la Edad Moderna todavía no se confunden unos con otros, a pesar de que forman parte de un mismo horizonte estamental que se habrá de tornar cada vez más heterogéneo con el paso del tiempo -el de la fidalguia- y de que, como hemos dicho, comparten un mismo modelo de reproducción social. Mientras que los primeros acceden al señorío a lo largo del siglo Xv y establecen sus mayorazgos a comienzos del xvI, en los cuales integran estos cotos como parte del patrimonio de sus casas (Torés en 1491 y 1514, Amarante en 1511, Taboada en 1522 y 1533 o Rubiáns en 1534); los segundos suelen retrasar el proceso hasta la segunda mitad del Quinientos y sus mayorazgos se constituyen generalmente entre mediados de dicho siglo y mediados del siguiente (San Damián en 1587, Outarelo en 1611 o Vilarxoán en 1648).

El proceso también tuvo diferentes consecuencias para las diversas partes que se vieron implicadas en este. En un primer plano, en el cual situamos a los propios hidalgos que acceden a las pequeñas o muy pequeñas jurisdicciones, la sujeción de dichos cotos en torno a una única línea sucesoria de la Casa dio lugar, en ocasiones, a la aparición de litigios entre distintos miembros del linaje cada vez que los derechos sucesorios eran puestos en tela de juicio originando disputas interfamiliares. De hecho, en ambos sectores se produjeron divisiones de estos pequeños señoríos entre los posibles herederos previamente a su integración en un mayorazgo (Taboada a comienzos del siglo xvi o familia Pallares, de Sarria, a inicios del xvII), a la cual no fueron ajenos en modo alguno sus vasallos, puesto que tuvieron que hacer frente a las consecuencias que se derivaban de dicha minifundización señorial. En segundo lugar, en la medida en que las casas de mayor antigüedad se valieron de la usurpación para hacerse con el control de algunos de estos cotos, hubo una parte implicada en el proceso -generalmente un señor eclesiástico- que comprobó cómo se redujeron los límites de sus señoríos a costa de la voracidad nobiliaria, viéndose obligada a recurrir a la vía judicial, al igual que los propios hidalgos, para hacer valer su derecho y reclamar la jurisdicción que le había sido usurpada. A ello debemos sumarle las desmembraciones eclesiásticas del Quinientos, de las cuales sacan partido tanto las casas con origen en la etapa bajomedieval como las que se constituyen durante la primera centuria moderna, pero que no habría afectado significativamente al señorío de abadengo en la segunda mitad del $\mathrm{XvI}^{86}$.

En último término, estos hidalgos reforzaron su poder en el ámbito local -bien sea directamente, o bien a través de sus funcionarios señoriales- al ver incrementada su capacidad de actuación debido a su condición de señores jurisdiccionales y las atribuciones que esta llevaba implícitas. Un análisis más pormenorizado de esta cuestión todavía requerirá de un nuevo trabajo específico centrado en los resortes

86. SaAvedra Fernández, P.: «Los señoríos de las grandes órdenes monásticas...», pp. 289-291. 
del poder señorial que pusieron en práctica tras haber accedido al señorío en esta primera etapa de la Edad Moderna, y que rebasa con creces los objetivos que nos planteamos al inicio del presente artículo; pero no cabe duda de que las querellas que presentaron en su contra sus vasallos ante la Real Audiencia de Galicia, ora apelando en segunda instancia una sentencia dictada en primera por la justicia señorial, ora acudiendo ya en primera para litigar contra su señor jurisdiccional, son una prueba manifiesta de que, amparándose en su condición señorial, estos pequeños o muy pequeños señores seculares no dudaron en cometer abusos que perjudicaron a sus propios vasallos.

\section{BibliografíA}

ARdiT, M.: «La historia rural de la España oriental durante la Edad Moderna: un estado de la cuestión», Stvdia Historica. Historia Moderna, 29, 2007, pp. 47-82.

Aponte, V. de: Recuento de las Casas Antiguas de Galicia, c. 1530-1535 (Ed. a cargo de C. Díaz y Díaz et al., Santiago de Compostela, Xunta de Galicia, 1986).

Atienza Hernández, I.: Aristocracia, poder y riqueza en la España moderna. La Casa de Osuna, siglos XV-XIX. Madrid, Siglo Veintiuno Editores, 1987.

BaZ VICENTE, M. ${ }^{a}$ J.: Señorío y propiedad foral de la alta nobleza en Galicia (siglos XVI-XX): La Casa de Alba. Madrid, Ministerio de Agricultura, Pesca y Alimentación, 1996.

Beceiro Pita, I.: El Condado de Benavente en el siglo Xv. Benavente, CECEL-CSIC, 1998.

Benítez SÁnchez-Blanco, R.: «Nobleza y señorío: el método», Cuadernos de Historia Moderna, 15, 1994, pp. 375-396.

Bermejo Cabrero, J. L.: «Sobre nobleza, señoríos y mayorazgos», Anuario de Historia del Derecho Español, LV, 1985, pp. 254-305.

BLESA CUÑAT, E.: «El règim senyorial valencià vespres de la seua dissolució», Estudis d'Historia Contemporània del País Valencià, 1, 1979, pp. 165-198.

Bouza-Brey Trillo, F.: El señorio de Villagarcía desde su fundación hasta su marquesado (1461-1655). Santiago de Compostela, Instituto de Estudios Gallegos Padre Sarmiento (CSIC), 1965.

Burgo López, C.: «El señorío monástico gallego en la Edad Moderna», Obradoiro de Historia Moderna, 1, 1992, pp. 99-121.

Carrasco Martínez, A.: El régimen señorial en la Castilla moderna: las tierras de la Casa del Infantado en los siglos XVII y XVIII. Madrid, Universidad Complutense, 1991.

Castro Pérez, F.: A Casa de Valladares. Formación e evolución do patrimonio dunha familia dominante na Pontevedra do Antigo Réxime. Pontevedra, Diputación Provincial de Pontevedra, 2004.

Clavero, B.: Mayorazgo. Propiedad feudal en Castilla (1369-1836). Madrid, Siglo Veintiuno Editores, 1974.

Díaz Álvarez, J.: «Los marqueses de Valdecarzana, señores de vasallos en la Asturias del Antiguo Régimen (siglos XvI-XvIII)», Revista de Historia Moderna, 24, 2006, pp. 363-394. 
Díaz-Castroverde Lodeiro, J. L.: El señorio de la Casa de Sonán en su jurisdicción, gobierno $y$ hacienda durante los siglos XVI al XX. Padrón (La Coruña), Novo Século, 1995.

Díaz-Castroverde Lodeiro, J. L.: Morgados e xurisdiccións na Terra e condado de Taboada. Séculos XV-XVIII. Guntín (Lugo), Asociación de Amigos do Mosteiro de Ferreira de Pallares, 2012.

Domínguez Ortiz, A.: Las clases privilegiadas en el Antiguo Régimen. Madrid, Istmo, 1973.

Eiras Roel, A.: «El señorío gallego en cifras. Nómina y ranking de los señores jurisdiccionales», Cuadernos de Estudios Gallegos, XXXVIII, 1989, pp. 113-135.

Eiras Roel, A.: «El régimen señorial en Galicia a finales de la Edad Moderna: Evaluación», Obradoiro de Historia Moderna, 6, 1997, pp. 7-46.

Erias Martínez, A. y González Fernández, X. M.: «O marco xurisdiccional na antiga provincia de Betanzos», Anuario Brigantino, 12, 1989, pp. 17-84.

Faya Díaz, M. ${ }^{a}$ A.: «Los señoríos eclesiásticos gallegos y la venta de jurisdicciones en tiempos de Felipe II», en Pereira Iglesias, J. L. y González Beltrán, J. M. a (eds.): Felipe II y su tiempo. Cádiz, 1999, pp. 101-115.

Fernández Cortizo, C.: «La orden de San Benito en la Galicia de la época moderna: La reforma de la Congregación de Castilla y las visitas generales», en López VÁzQuez, J. M. (coord.): Opus Monasticorum. Patrimonio, Arte, Historia y Orden. Santiago de Compostela, Xunta de Galicia, 2005, pp. 23-95.

Fernández Cortizo, C.: «A regular observancia, quebrada: visita e reforma dos mosteiros galegos dos relixiosos da Orde de San Bieito en tempos dos Reis Católicos», en Fernández Castiñeiras, E. y Monterroso Montero, J. M. (coords.): Opus Monasticorum II. Arte beneditina nos camiños de Santiago. Santiago de Compostela, Xunta de Galicia, 2006, pp. 81-109.

Fernández Suárez, G. F.: La Nobleza Gallega entre los siglos XIV-XV. Los Sarmiento. Condes de Ribadavia. Santiago de Compostela, El Eco Franciscano, 2002.

FERnÁndez SuÁrez, G. F.: «La administración del Condado de Ribadavia en el siglo xv: organización político-judicial, hacienda, milicia, casa y comitiva», Semata. Ciencias Sociais e Humanidades, 15, 2004, pp. 343-361.

Fernández Vega, L.: La Real Audiencia de Galicia, órgano de gobierno en el Antiguo Régimen (1480-1808), 3 vols. La Coruña, Diputación Provincial de La Coruña, 1982.

Ferro Couselo, X.: «Gente llana con ventura. Los Boanes», Boletín Avriense, II, 1972, pp. 7-73.

Framiñán Santas, A. M. ${ }^{a}$ y García G. Ledo, X. A.: «Os Costela, fidalgos da Casa de Moscoso», Descubrindo DEZA. Anuario de Estudios e Investigación, 6, 2004, pp. 145-167.

Gallego Domínguez, O.: La organización administrativa territorial de la antigua provincia de Ourense a mediados del siglo XVIII. Orense, Museo Arquelógico Provincial de Orense, 1988.

Gallego Domínguez, O.: "Os arquivos da nobreza e o seu tratamento arquivístico», en VV. AA.: Conserva-la memoria. Novas adquisicións da Consellería de Cultura 
e Xuventude para o Arquivo do Reino de Galicia. Santiago de Compostela, Xunta de Galicia, 1993, pp. 63-81.

Gallego Domínguez, O.: «Mercedes de los condes de Ribadavia a dos hidalgos de la jurisdicción de Valdeorras», Boletín Avriense, XXXI, 2001, pp. 131-141.

García Acuña, M. ${ }^{a}$ L.: «Mecanismos de control señorial: Los juicios de residencia en el Estado de Ribadavia», Obradoiro de Historia Moderna, 5, 1996, pp. 119-134.

GARcía Hernán, D.: El gobierno señorial en Castilla. La presión y concesión nobiliaria en sus documentos (siglos XVI-XVIII). Madrid, Biblioteca Nueva, 2011.

GARcía Oro, J.: La nobleza gallega en la Baja Edad Media. Las casas nobles y sus relaciones estamentales. Santiago de Compostela, Bibliófilos Gallegos, 1981.

García Oro, J.: Don Diego Sarmiento de Acuña, conde de Gondomar y embajador de España (1567-1626). Santiago de Compostela, Xunta de Galicia, 1997.

García Oro, J. y Portela Silva, M. ${ }^{\mathrm{a}}$ J.: «El señorío eclesiástico gallego y la Corona en el siglo XVI», Estudios Mindonienses, 17, 2001, pp. 13-275.

García Oro, J. y Portela Silva, M. J.: «Osorios, Bolaños, Pardos y Ribadeneiras: Las casas nobles lucenses, camino de la Modernidad», Anuario Brigantino, 25, 2002, pp. 151-180.

García Oro, J. y Portela Silva, M. J.: La Casa de Altamira durante el Renacimiento. Estudio introductorio y colección diplomática. Santiago de Compostela, El Eco Franciscano, 2003.

García Tato, I.: Vilanova, Outarelo y San Francisco Blanco. Monografía histórica de una parroquia gallega. Barco de Valdeorras (Orense), Instituto de Estudios Valdeorreses, 1999.

Guilarte, A. M.: El régimen señorial en el siglo XVI. Valladolid, Universidad de Valladolid, 1987, 2. ${ }^{\mathrm{a}}$ ed.

Huppert, G.: Bourgeois et gentilshommes. La réussite sociale en France au XVI siècle. París, Flammarion, 1983.

Iglesias Blanco, A. S.: A Casa de Xunqueiras nos séculos XVIII e XIX. Contribución ó estudio das economias fidalgas. Valga (Pontevedra), Ayuntamiento de Valga, 2004.

Iglesias Blanco, A. S.: La Casa de Amarante. Siglos XVI-XIX. Santiago de Compostela, Universidad de Santiago de Compostela, 2008, tesis de doctorado editada en CD-ROM.

López, P.: «Historia del Pazo de Oca», Boletín Auriense, XIV-XV, 1986, pp. 143-171.

López DíAz, M.a: «Alteraciones en el mapa jurisdiccional gallego durante la Edad Moderna: las desmembraciones eclesiásticas del siglo XvI», Estudios Mindonienses, 7, 1991, pp. 559-588.

López Díaz, M.a: Señorío y Municipalidad. Concurrencia y conflicto de poderes en la ciudad de Santiago (siglos XVI-XVII). Santiago de Compostela, Universidad de Santiago de Compostela y Consorcio de Santiago, 1997.

López Díaz, M. a: «La administración de la justicia señorial en el antiguo régimen», Anuario de Historia del Derecho Español, LXXVI, 2006, pp. 557-588. 
López Díaz, M. ${ }^{a}$ y SaAvedra Vázquez, M. ${ }^{a}$ C.: «Historia política y de las instituciones del Antiguo Régimen en Galicia», en López López, R. J. y GonzÁlez Lopo, D. L. (eds.): Balance de la Historiografía Modernista, 1973-2001. Santiago de Compostela, Xunta de Galicia, 2003.

López-Salazar PÉrez, J.: «El espejo del mal señor. El señorío de Almodóvar del Pinar durante el siglo XVI», Cuadernos de Historia Moderna, 16, 1995, pp. 259-292.

Mariño VeIras, D.: Señorío de Santa María de Meira (ss. XII-XVI). La Coruña, Ediciones Nos, 1983.

Migués Rodríguez, V. M.: As terras, as pousas e os vinculeiros. A fidalguía galega na Época Moderna. Sada (La Coruña), Edicións do Castro, 2002.

Migués Rodríguez, V. M.: Os Arquivos Privados e a Nobreza: un Apuntamento Histórico-Arquivístico. O caso galego a través do fondo do Marquesado de "San Martín» de Ombreiro [ARG]. La Coruña, Xunta de Galicia, 2002.

Moxó, S. de: «Las desamortizaciones eclesiásticas del siglo XvI», Anuario de Historia del Derecho Español, XXXI, 1961, pp. 327-361.

Moxó, S. de: «El señorío, legado medieval», Cuadernos de Historia, 1, 1967.

Olivera Serrano, C.: «La Galicia de Vasco de Aponte: los pleitos del arzobispo Tabera contra los linajes de la Tierra de Santiago», En la España Medieval, 22, 1999, pp. 285-315.

Pardo de Guevara, E.: Los señores de Galicia. Tenentes y condes de Lemos en la Edad Media, 2 vols. La Coruña, Fundación Pedro Barrié de la Maza, 2000.

Pérez García, J. M. y López Díaz, M.a: «La historiografía modernista de Galicia: balance historiográfico (1988-2008)», Minius. Historia, Arte e Xeografía, 18, 2010, pp. 147-206.

Presedo Garazo, A.: Dueños y señores de casas, torres y pazos, 1500-1900 (Contribución al estudio de la fidalguía gallega), 2 vols. Santiago de Compostela, Universidad de Santiago de Compostela, 2001, tesis de doctorado inédita.

Presedo Garazo, A.: A Fidalguía Galega. Estudos sobre a reprodución social dos fidalgos na Galicia Moderna. Santiago de Compostela, Lóstrego, 2008.

Presedo Garazo, A.: «Las casas nobles gallegas y su relación con los monasterios de la Diócesis de Santiago de Compostela en la temprana Edad Moderna (1454-1556)», en Casal, R., Andrade, J. M. y López López, R. J. (eds.): Galicia Monástica. Estudos en lembranza da profesora María José Portela Silva. Santiago de Compostela, Universidad de Santiago de Compostela, 2009, pp. 227-243.

Presedo Garazo, A.: Nobleza y régimen señorial en Galicia. La Casa Montaos en los siglos XVI y XVII. Santiago de Compostela, Universidad de Santiago de Compostela, 2011.

Presedo Garazo, A.: «La imagen del poder de los hidalgos gallegos en la Época Moderna», Obradoiro de Historia Moderna, 20, 2011, pp. 221-250.

Río BarJa, F. X.: Cartografía xurisdiccional de Galicia no século XVIII. Santiago de Compostela, Consello da Cultura Galega, 1990.

Rionegro Fariña, I.: «Una familia de poder de la élite orensana: los Boán», en López Díaz, M. ${ }^{a}$ (ed.): Cuadernos Feijonianos de Historia Moderna IV. Santiago de Compostela, Andavira, 2013, pp. 107-127. 
Rodríguez González, A.: «Documentación Medieval del Archivo Diocesano de Santiago: Libro de feudos de diferentes bienes, feligresías, cotos y jurisdicciones», Compostellanum, XXXVII, 1992, pp. 373-462.

SaAvedra Fernández, P.: «Los montes abiertos y los concejos rurales en Galicia en los siglos XVI-XviII: aproximación a un problema», Cuadernos de Estudios Gallegos, 98, 1982, pp. 179-236.

SaAvedra Fernández, P.: «Contribución al estudio del régimen señorial gallego», Anuario de Historia del Derecho Español, LIX, 1990, pp. 103-184.

SaAvedra Fernández, P.: «Régimen señorial y administración local en la Galicia de los siglos XVI-XVIII», en Barreiro FernándeZ, X. R. y González Mariñas, P. (coords.): Historia da Administración. Santiago de Compostela, Escola Galega de Administración Pública, 1994, pp. 29-62.

SaAvedra Fernández, P.: «La administración señorial en la Galicia Moderna», Hispania. Revista Española de Historia, 198, 1998, pp. 185-212.

SAAvedra Fernández, P.: «Los señoríos de las grandes órdenes monásticas en la Galicia moderna: una visión global», en López DíAz, M. ${ }^{a}$ (ed.): Estudios en homenaje al profesor José M. Pérez García. Vol. 2. Historia y Modernidad. Vigo, Universidad de Vigo, 2009, pp. 277-305.

Sánchez Cabrera, M. ${ }^{a}$ C.: El Bajo Miño en el siglo XV. El espacio y los hombres. La Coruña, Fundación Pedro Barrié de la Maza, 1997.

Vaamonde Gamo, A.: «El archivo de los Vaamonde en la Casa de Ouces», Anuario Brigantino, 18, 1995, pp. 77-82.

Vaquero Díaz, M. ${ }^{a}$ B.: Colección diplomática do mosteiro de san Salvador de Celanova (ss. XIII-XV), 4 vols. Santiago de Compostela, Tórculo, 2004.

VÁzquez Bertomeu, M.: La Hacienda Arzobispal Compostelana. Libros de recaudación (1481-83 y 1486-91). Santiago de Compostela, Instituto de Estudios Gallegos Padre Sarmiento (CSIC), 2002.

VÁzquez Bertomeu, M.: «Escritura y sociedad en la Galicia moderna: reflexiones a propósito del archivo de la casa de Mirapeixe», Estudios Mindonienses, 20, 2004, pp. 893-915.

Vázquez Lijó, J. M.: Luces sobre a Casa de Goiáns no Antigo Réxime, Boiro (La Coruña), Ayuntamiento de Boiro-Xunta de Galicia, 2012.

Yun Casalilla, B.: «Notas sobre el régimen señorial en Valladolid y el estado señorial de Medina de Rioseco en el siglo XvII», Investigaciones Históricas, 3, 1982, pp. 143-175. 
